\title{
Iraq/Afghanistan-era Veterans with back pain: Characteristics and predictors of compensation and pension award
}

\author{
Carine J. Sakr, MD, MPH; ${ }^{1-2^{*}}$ Anne C. Black, PhD; ${ }^{1-2}$ Martin D. Slade, MPH; ${ }^{2}$ Justin Calfo, BA; $^{2}$ Marc I. \\ Rosen, $\mathbf{M D}^{1-2}$ \\ ${ }^{1}$ Department of Veterans Affairs Connecticut Healthcare System, West Haven, CT; ${ }^{2}$ Yale University School of Medi- \\ cine, New Haven, CT
}

\begin{abstract}
Approximately 440,000 U.S. Veterans receive compensation for back and/or neck conditions. Veterans Benefits Administration (VBA) criteria state that back compensation determinations are based on impaired back function and not comorbidity or lifestyle, but whether compensation is based solely on consideration of the lumbosacral region is unknown. In this study, we conducted a cross-sectional analysis of medical chart data from 178 post-9/11 Veterans applying for service connection for back pain in fiscal year 2012 at the Department of Veterans Affairs Connecticut Healthcare System. Altogether, $62 \%$ were noted to have impairment of back functioning and $74 \%$ were awarded compensation. Rates of comorbidities (obesity, depression, smoking, and illicit drug use) were high. In multivariate models predicting compensation awarded, only having an impaired back was associated with service-connected compensation. Pain was associated with extent of service connection, but this relationship was fully mediated by functional back impairment. No other measure (including work status) significantly predicted compensation. In summary, service connection was largely based on functional impairment, as called for in VBA criteria. Although pain and comorbidities undoubtedly affect day-to-day functioning, these factors were not independently related to service connection. Veterans present with many remediable conditions, and the service-connection evaluation may be an opportunity to engage them in treatment.
\end{abstract}

Key words: back pain, compensation, disability, employment, functional impairment, OEF, OIF, OND, pension, service connection, VBA, Veterans.

\section{INTRODUCTION}

Back pain is the most common cause of chronic noncancer pain among Veterans [1]. Among Operation Iraqi Freedom, Operation Enduring Freedom, and Operation New Dawn (OIF/OEF/OND) Veterans receiving treatment at Department of Veterans Affairs (VA) healthcare facilities in the United States between 2001 and 2009, 17.5 percent were diagnosed with lower back pain conditions within $7 \mathrm{yr}$ of deployment [2].

Veterans' back pain may be the basis for an application for benefits if the pain was the result of active service. The Veterans Benefits Administration (VBA) provides financial compensation to Veterans with service-connected

\footnotetext{
$\overline{\text { Abbreviations: } \mathrm{BMI}}=$ body mass index, $\mathrm{C} \& \mathrm{P}=$ compensation and pension, DBQ $=$ Disability Benefits Questionnaire, $\mathrm{OEF}=$ Operation Enduring Freedom, OIF $=$ Operation Iraqi Freedom, OND $=$ Operation New Dawn, OR $=$ odds ratio, PHQ-9 = Patient Health Questionnaire, PTSD = posttraumatic stress disorder, VA = Department of Veterans Affairs, VBA = Veterans Benefits Administration.

*Address all correspondence to Carine J. Sakr, MD, MPH; Yale Occupational and Environmental Medicine Program, 367 Cedar St, Harkness Annex, Room 212, New Haven, CT 06510; 203-785-6434; fax: 203-785-7391.

Email: carine.sakr@yale.edu http://dx.doi.org/10.1682/JRRD.2015.08.0151
} 
conditions [3]. Compensation is a tax-free monetary benefit paid to Veterans for each disability that is the result of disease or injury incurred or aggravated during active military service. Service connection is the determination that an injury or disease resulting in vocational impairment is linked to service in the military; the determination entitles the injured Veteran to benefits. A Veteran begins the compensation and pension (C\&P) evaluation process by submitting a claim that he or she is entitled to compensation for a condition. A clinician then examines the Veteran and completes a comprehensive evaluation, which is submitted to the VBA for adjudication. The percentage of service-connection entitlement for each condition may be rated from 0 to 100 percent, with 0 percent representing a condition that is not associated with any harm or impairment (and thus no compensation or services for that condition) and 100 percent representing a condition that would cause an average person to lose all ability to perform activities of daily living (and thus merit full compensation for that condition). The amount of compensation depends on the sum of the percentage service connection for each individual condition (with some exceptions) and the number of dependents [3].

By the end of fiscal year 2013, 3.74 million Veterans (17\% of the total number of Veterans) were receiving disability compensation from the VA [4-5]. Lumbosacral or cervical strain (a primary cause of back pain) was the sixth most prevalent condition (440,795 Veterans) for which Veterans received compensation. Despite the high prevalence of back pain among Veterans and the substantial harm it causes [1-6], we are aware of no published research describing Veterans applying for service connection for musculoskeletal conditions or for lumbosacral (back) conditions, specifically.

VBA policies specify that service connection should be based on loss or impairment of back function [7], with pain considered to the extent that it results in restricted back function. An effect of this policy is to minimize compensation for pain per se, which may be affected by compensation-seeking [8-10]. However, the inability of the back to function normally because of pain may relate to factors known to affect pain: mood and type of activities engaged in and other factors, such as incentives [1113]. The extent to which these and other factors relate to service-connection determinations for painful conditions has not been described. Studies examining Veterans' claims for mental health conditions suggest extraneous factors such as race, sex, and geographic location of the
Veteran may influence determinations [14-18]. Thus, our models explored the effect of influences other than pain and function on service-connection determinations for back pain.

In this study, we first described the characteristics of Veterans applying for C\&P for back pain. We then analyzed factors associated with impaired back function and the ultimate service-connection determination. Pain, employment status, and comorbid conditions were among the predictors considered.

\section{METHODS}

\section{Data Extraction}

The study was a cross-sectional analysis of data from OIF/OEF/OND Veterans applying for C\&P for back pain for the first time. Veterans were those who applied in fiscal year 2012 and were evaluated at the VA Connecticut Healthcare System. Information was obtained by a member of the research team who reviewed Veterans' electronic records in the VA Computerized Patient Record System and completed a chart extraction form.

A key portion of the medical record was the Disability Benefits Questionnaire (DBQ) completed during the C\&P examination. DBQs are medical examination forms with fields for information needed to evaluate disability C\&P claims [19]. The disability-related questions in the DBQ were designed to be completed using an electronic point-and-click format [20]. The DBQ is completed by a clinician and then reviewed by staff of the VBA, at which point a percentage service connection is determined.

\section{Study Sample}

Data extraction occurred between September 2013 and February 2014. Using an administrative report, we identified all Veterans who underwent a C\&P evaluation for back pain at the VA Connecticut Healthcare System in fiscal year 2012. We further restricted our sample to Veterans who served in OIF/OEF/OND as indicated by the Veterans' period of service having been listed as $\mathrm{OIF} /$ $\mathrm{OEF} / \mathrm{OND}$, the Veteran having been younger than $36 \mathrm{yr}$ of age, or the Veteran having ended combat status after 2003. In order to focus analyses on the service-connection determination from the 2012 claim, we excluded Veterans whose original service-connection percentages could not be determined because there had been a subsequent 
evaluation that might have overwritten the original percentage in the medical record.

\section{Measures}

\section{Degree of Pain}

The degree of pain, self-described on a 10-point scale, was extracted from free-text entries in the medical history section of the DBQ. We separately recorded degree of pain with and without medications when these were differentiated in the chart. For data analyses, degree of pain represented degree of pain without medication, unless degree of pain with medication was recorded, in which case it was used instead.

\section{Depression}

Depression was summarized as the score on the Patient Health Questionnaire (PHQ-9), which was completed during clinic visits immediately before the disability evaluation. The PHQ-9 is a self-reported 9-question instrument used for screening and diagnosing depression. It is a reliable and valid measure of depression severity and has been used extensively as a clinical and research tool [21].

\section{Service Connection}

Service connection was recorded from the patient's electronic health record and reflected the degree of disability rating determined by VBA. We extracted separate ratings for back disability, posttraumatic stress disorder (PTSD), and all conditions combined.

\section{Functional Impairment}

Functional impairment was recorded in the DBQ back questionnaire completed during the $\mathrm{C} \& \mathrm{P}$ examination. The question asked, "Does the veteran have any functional loss and/or functional impairment of the thoracolumbar spine (back)?" Examples of functional impairment listed later in the DBQ include "pain on movement," "excess fatigability," and "interference with sitting, standing, and/or weight bearing."

\section{Other Measures from Disability Benefits Questionnaire}

Other variables of interest that were extracted from the DBQ included number of deployments, cause of injury, and work status at the time of the C\&P examination.

\section{Other Measures from Electronic Health Record}

Age, sex, body mass index (BMI), and race were copied from the electronic health record. Smoking status at the date of the C\&P examination was also recorded. Additionally, use of prescribed opioid medications and any evidence of illegal drug use (e.g., cocaine, cannabis, or heroin) at any point during the 12 mo prior to the C\&P examination were collected from the electronic health record.

\section{Statistical Analyses}

Descriptive statistics were calculated to characterize the study sample, including mean service connection for back pain and PTSD and total service connection. Veterans with complete data were compared to those with missing data using $t$-tests for continuous variables and chi-square tests for categorical variables.

\section{Bivariate Correlation Analyses}

The relationship between pain, functional impairment, and service connection was first explored by examining all bivariate correlations.

\section{Regression Modeling}

We created an ordinal variable for percentage service connection for back pain: (1) 0 percent, (2) $>0$ percent but $\leq 20$ percent, and (3) $>20$ percent. Multivariate ordinal logistic regression analysis was used to model service connection for back pain as a function of functional impairment of the back as well as the following covariates: age, sex, race, BMI, work status, smoking status, use of illegal drugs, use of prescribed opioids, and degree of depression. A backward-elimination strategy was used, requiring a significance level of 0.05 to remain in the model. Building on the parsimonious model of service connection derived with the full sample, we then added pain with the subset of Veterans who had data for that variable $(n=68)$. Finally, we specified a path model to estimate the mediating effect of functional impairment on the association between back pain and service connection.

All statistical analyses were performed using SAS 9.3 (SAS Institute Inc; Cary, North Carolina), with statistical significance defined at 95 percent confidence level $(\alpha=0.05)$. 


\section{RESULTS}

\section{Sampling and Participant Characteristics}

We identified 655 Veterans who filed a back condition claim within VA Connecticut Healthcare System in fiscal year 2012. We then restricted the sample to Veterans who served during OIF/OEF/OND, who were evaluated for the first time in fiscal year $2012(n=190)$, and who had not had any subsequent back condition C\&P evaluations (final $N=178$ ).

Characteristics of the study sample are described in Table 1. The majority of the Veterans were men (91\%), and the mean age was 36 yr. Of the 168 Veterans whose data were available, 15 percent were normal weight, 42 percent were overweight, and another 43 percent were obese. Current smokers represented 39 percent of the sample; 21 percent of the Veterans had been prescribed opioids in the preceding $12 \mathrm{mo}$, and 17 percent had been using illegal drugs.

The median rating for service connection for back pain was 10 percent. The 75 th percentile was 20 percent, and only 5 percent had a rating of 50 percent or higher. Mean service-connection percentage for back pain and PTSD and total service connection are reported in Table 1.

Table 1.

Description of study sample (continuous and categorical variables; $N=$ 178 unless otherwise noted).

\begin{tabular}{|c|c|}
\hline & $\begin{array}{c}\text { Mean } \pm \text { SD } \\
\text { or } n(\%)\end{array}$ \\
\hline$\overline{\mathrm{Age}}$ & $35.7 \pm 8.4$ \\
\hline \multicolumn{2}{|l|}{ Sex } \\
\hline Male & $162(91.0)$ \\
\hline Female & $16(9.0)$ \\
\hline \multicolumn{2}{|l|}{ Race $(n=167)$} \\
\hline Black & $25(15.0)$ \\
\hline Hispanic & $24(14.3)$ \\
\hline White & $112(67.1)$ \\
\hline Other & $6(3.6)$ \\
\hline $\operatorname{BMI}(n=168)$ & $29.2 \pm 4.1$ \\
\hline \multicolumn{2}{|l|}{ BMI Category $(n=168)$} \\
\hline Normal & $25(14.9)$ \\
\hline Overweight & $70(41.7)$ \\
\hline Obese & $73(43.4)$ \\
\hline \multicolumn{2}{|l|}{ Cause of Injury } \\
\hline Holding/Carrying & $51(28.7)$ \\
\hline Lifting & $30(16.9)$ \\
\hline Motor Vehicle Accident & $10(5.6)$ \\
\hline Repetitive Motion & $7(3.9)$ \\
\hline Slip/Trip/Fall & $22(12.4)$ \\
\hline
\end{tabular}

Table 1. (cont)

Description of study sample (continuous and categorical variables; $N=$ 178 unless otherwise noted).

\begin{tabular}{|c|c|}
\hline & $\begin{array}{c}\text { Mean } \pm \text { SD } \\
\text { or } n(\%)\end{array}$ \\
\hline Struck by Object/Explosion & $26(14.6)$ \\
\hline Twisting & $10(5.6)$ \\
\hline Other/Unknown & $22(12.4)$ \\
\hline \multicolumn{2}{|c|}{ Work Status at C\&P Examination $(n=177)$} \\
\hline Active & $124(70.1)$ \\
\hline Inactive & $53(29.9)$ \\
\hline \multicolumn{2}{|l|}{$\%$ Service Connection for Back } \\
\hline 0 & $46(25.8)$ \\
\hline 10 & $80(44.9)$ \\
\hline 20 & $23(12.9)$ \\
\hline 30 & $7(3.9)$ \\
\hline 40 & $13(7.3)$ \\
\hline 50 & $2(1.1)$ \\
\hline 60 & $5(2.8)$ \\
\hline 70 & $1(0.6)$ \\
\hline 80 & $1(0.6)$ \\
\hline \multicolumn{2}{|l|}{ Functional Impairment } \\
\hline Yes & $110(61.8)$ \\
\hline No & $68(38.2)$ \\
\hline Degree of Pain $(n=68)$ & $5.4 \pm 2.2$ \\
\hline \multicolumn{2}{|l|}{ Degree of Depression $(n=170)$} \\
\hline None & $112(65.9)$ \\
\hline Mild & $15(8.8)$ \\
\hline Moderate & $19(11.2)$ \\
\hline Moderate/Severe & $11(6.5)$ \\
\hline Severe & $13(7.7)$ \\
\hline \multicolumn{2}{|l|}{ Illegal Drug Use } \\
\hline Yes & $30(16.9)$ \\
\hline No & $148(83.1)$ \\
\hline \multicolumn{2}{|l|}{ Prescribed Opioid Use } \\
\hline Yes & $37(20.8)$ \\
\hline No & $141(79.2)$ \\
\hline \multicolumn{2}{|l|}{ Current Smoker $(n=174)$} \\
\hline Yes & $67(38.5)$ \\
\hline No & $107(61.5)$ \\
\hline \multicolumn{2}{|c|}{ Physical Therapy Within Previous 6 mo $(n=177)$} \\
\hline Yes & $125(70.6)$ \\
\hline No & $52(29.4)$ \\
\hline \multicolumn{2}{|l|}{ VA Care Within Previous 6 mo } \\
\hline Yes & $165(92.7)$ \\
\hline No & $13(7.3)$ \\
\hline$\%$ Service Connection for Back & $14.3 \pm 15.5$ \\
\hline$\%$ Service Connection for PTSD & $25.2 \pm 30.7$ \\
\hline \% Service Compensation Total & $58.5 \pm 27.2$ \\
\hline
\end{tabular}


Despite 62 percent of the sample having functional impairment from their back condition noted during the evaluation, 70 percent were working at the time of their $\mathrm{C} \& \mathrm{P}$ examination. Among Veterans who had functional impairment, 66 percent were working compared with 76 percent of those who did not report functional impair- ment; these differences in employment rates were not statistically significant $\left(\chi^{2}(1)=1.89, p=0.17\right)$.

\section{Comparison Between Subjects with Complete Data and Those with Missing Data for Pain}

Table 2 shows the comparison between Veterans

Table 2.

Comparison between Veterans with and without pain data. Data presented as $n(\%)$ or mean \pm standard deviation.

\begin{tabular}{|c|c|c|c|}
\hline Parameter & $\begin{array}{l}\text { Subjects with Pain Data } \\
\qquad(n=68)\end{array}$ & $\begin{array}{l}\text { Subjects with No Pain Data } \\
\qquad(n=110)\end{array}$ & $p$-Value* \\
\hline \multicolumn{4}{|l|}{ Functional Impairment } \\
\hline Yes & $48(70.6)$ & $62(56.4)$ & 0.08 \\
\hline No & $20(29.4)$ & $48(43.6)$ & \\
\hline \multicolumn{4}{|c|}{ Work Status at C\&P Examination } \\
\hline Inactive & $21(30.9)$ & $32(29.4)$ & 0.87 \\
\hline Active & $47(69.1)$ & $77(70.6)$ & \\
\hline \multicolumn{4}{|l|}{ Race } \\
\hline Black & $7(10.3)$ & $18(16.4)$ & 0.39 \\
\hline Hispanic & $11(16.2)$ & $13(11.8)$ & \\
\hline Unknown & $3(4.4)$ & $8(7.3)$ & \\
\hline Other & $4(5.9)$ & $2(1.8)$ & \\
\hline White & $43(63.2)$ & $69(62.7)$ & \\
\hline \multicolumn{4}{|l|}{ Current Smoker } \\
\hline Yes & $22(32.4)$ & $45(42.5)$ & 0.20 \\
\hline No & $46(67.7)$ & $61(57.6)$ & \\
\hline \multicolumn{4}{|l|}{ Sex } \\
\hline Female & $6(8.8)$ & $10(9.1)$ & $>0.999$ \\
\hline Male & $62(91.2)$ & $100(90.9)$ & \\
\hline \multicolumn{4}{|l|}{ Illegal Drug Use } \\
\hline Yes & $14(20.6)$ & $16(14.6)$ & 0.31 \\
\hline No & $54(79.4)$ & $94(85.5)$ & \\
\hline \multicolumn{4}{|l|}{ Prescribed Opioid Use } \\
\hline Yes & $15(22.1)$ & $22(20.0)$ & 0.85 \\
\hline No & $53(77.9)$ & $88(80.0)$ & \\
\hline \multicolumn{4}{|l|}{ Degree of Depression } \\
\hline None & $43(63.2)$ & $69(62.7)$ & 0.18 \\
\hline Mild & $8(11.8)$ & $7(6.9)$ & \\
\hline Moderate & $11(16.2)$ & $8(7.8)$ & \\
\hline Moderately Severe & $2(2.9)$ & $9(8.8)$ & \\
\hline Severe & $4(5.9)$ & $9(8.8)$ & \\
\hline Age & $34.9 \pm 8.6$ & $36.2 \pm 8.2$ & 0.29 \\
\hline BMI & $29.1 \pm 4.1$ & $29.3 \pm 4.1$ & 0.76 \\
\hline \multicolumn{4}{|c|}{$\begin{array}{l}\text { Note: } n \text {-values for Work Status at C\&P, Current Smoker, and Degree of Depression for Subjec } \\
\text { missing data. } \\
\text { "Fisher exact test for categorical variables and comparison of means for continuous variables. } \\
\text { BMI = body mass index, } \mathrm{C} \& \mathrm{P}=\text { compensation and pension. }\end{array}$} \\
\hline
\end{tabular}


with complete data and those with missing data for pain. There was no significant difference on any measured variable between the two groups.

\section{Bivariate Correlations}

All bivariate correlations among service connection for back pain, pain, and functional impairment variables were positive and statistically significant (service connection: pain $r=0.25, p=0.04$; service connection: functional impairment $r=0.33, p<0.01$; pain: functional impairment $r=0.39, p<0.01$ ).

\section{Predictors of Back Functional Impairment}

In the logistic regression model, only pain predicted back functional impairment (odds ratio [OR] 1.61, $p<$ 0.01 ). For each unit increase on the pain scale, the risk of functional impairment increased by 61 percent. All other covariates (age, sex, race, BMI, work status, smoking, illegal drugs, opiate use, and degree of depression) were not associated with back functional impairment.

\section{Ordinal Regression of Service Connection}

In the multivariate ordinal logistic regression model utilizing all subjects, only functional impairment predicted service connection for back pain (OR 4.03, $p<$ 0.001). Results of the full model and the parsimonious models are reported in Table 3.

In the subsample of Veterans with pain data, when controlling for functional impairment, the effect of pain on service connection was not statistically significant $(\mathrm{OR}=1.21, p=0.14)$.

\section{Mediation Model}

Path analysis demonstrated the full mediation of the relationship between pain and service connection by functional impairment (Figure). The significant bivariate association between pain and service connection was fully accounted for by functional impairment.

\section{DISCUSSION}

Veterans applying for service connection for back conditions had painful, impaired backs. The average pain rating was 5.4 on a 10-point scale, and the majority of Veterans $(62 \%)$ had limited back function. It is noteworthy that 70 percent had received some physical therapy for their condition in the preceding $12 \mathrm{mo}$.
Evidence of comorbidity is that the mean serviceconnection rating for the back condition was only 14 percent, but the mean overall service-connection rating was 59 percent. The difference (45\%) reflects disabilities that resulted from other conditions. Veterans in this sample also had high rates of PTSD, depression, substance use, and overweight and obesity. The rates of elevated BMI in our sample were higher than those reported in other groups of Veterans [22-23]. The prevalence of smoking was similar to that reported among other OIF/OEF/OND Veterans [24-26].

The VBA rating criteria require that service connection be based on functional impairment, and in fact, none of the comorbidities, demographic factors, or measures of other systems was significantly associated with service connection. Although pain can lead to a number of other disorders, pain was only relevant to the extent that it affected function. The study data reflect VBA's restricted focus on impaired back function.

One consequence of determining compensation narrowly focused on the condition of the back is that it might underestimate the true, real-life effect of back impairment on Veterans who have comorbid conditions. The evaluation of a back condition does not consider whether it worsens another physical or mental condition. However, any other condition proximately worsened by a service-connected back condition can be separately service connected as secondary to the back condition.

The VBA rating criteria also direct raters to determine the effect of impairments they detect on "the person's ordinary activity" and not on employment specifically [27]. In fact, in this study, the majority of OIF/OEF/OND Veterans applying for C\&P for back pain were working, despite a number of health problems. The Veterans in this study who were employed received no less service connection than those who were not employed. The advantage of separating impairment from specific vocational functioning is that it removes a potential disincentive to work for Veterans receiving service connection. Prior studies have noted that Veterans highly value their ability to work [28] and that adults with back pain benefit from being employed [29].

The main limitation of this study is its small sample size. The model that included the pain data was based on 68 Veterans. However, when we compared those Veterans to the rest of the study sample, there were no significant differences in their characteristics. Another limitation is associated with the use of the electronic 
Table 3.

Predictors of service connection for back pain.

\begin{tabular}{|c|c|c|c|}
\hline Parameter & Point Estimate (OR) & $95 \% \mathrm{CI}$ & p-Value \\
\hline \multicolumn{4}{|l|}{ Full Model } \\
\hline \multicolumn{4}{|l|}{ Work Status at C\&P Examination } \\
\hline Active & 0.68 & 0.33 to 1.39 & 0.29 \\
\hline Inactive & 1 (ref) & - & \\
\hline \multicolumn{4}{|l|}{ Functional Impairment } \\
\hline Yes & 4.05 & 1.98 to 8.25 & $<0.001$ \\
\hline No & 1 (ref) & - & \\
\hline Age on 2014 Jul 1 (per yr) & 0.99 & 0.95 to 1.03 & 0.50 \\
\hline \multicolumn{4}{|l|}{ Race } \\
\hline Black & 0.43 & 0.17 to 1.11 & 0.33 \\
\hline Hispanic & 0.54 & 0.20 to 1.44 & \\
\hline Other & 0.63 & 0.12 to 3.51 & \\
\hline Unknown & 1.61 & 0.32 to 8.15 & \\
\hline White & 1 (ref) & - & \\
\hline BMI (per unit) & 1.07 & 0.98 to 1.16 & 0.13 \\
\hline \multicolumn{4}{|l|}{ Current Smoker } \\
\hline Yes & 0.65 & 0.33 to 1.31 & 0.23 \\
\hline No & 1 (ref) & - & \\
\hline \multicolumn{4}{|l|}{ Sex } \\
\hline Female & 1.13 & 0.35 to 3.64 & 0.84 \\
\hline Male & 1 (ref) & - & \\
\hline \multicolumn{4}{|l|}{ Illegal Drug Use } \\
\hline Yes & 1.76 & 0.72 to 4.30 & 0.21 \\
\hline No & 1 (ref) & - & \\
\hline \multicolumn{4}{|l|}{ Prescribed Opioid Use } \\
\hline Yes & 0.83 & 0.37 to 1.86 & 0.65 \\
\hline No & 1 (ref) & - & \\
\hline \multicolumn{4}{|l|}{ Degree of Depression } \\
\hline None & 1.62 & 0.48 to 5.41 & 0.93 \\
\hline Mild & 1.68 & 0.36 to 7.90 & \\
\hline Moderate & 1.98 & 0.46 to 8.51 & \\
\hline Moderately Severe & 1.61 & 0.30 to 8.76 & \\
\hline Severe & 1 (ref) & - & \\
\hline \multicolumn{4}{|c|}{ Parsimonious Model: Functional Impairment } \\
\hline Yes & 4.03 & 2.08 to 7.84 & $<0.001$ \\
\hline No & 1 (ref) & - & \\
\hline
\end{tabular}

health record as the main source of data. Many of the measures, such as use of prescribed opioids, use of illicit drugs, and use of physical therapy, were likely accurate when they were indicated in the medical record but were false negatives if their omission from the medical record was because they had not been asked about and/or reported. Finally, although we explored the effect of multiple variables available in the existing data set, others not measured, such as Veterans' income and education, may also influence service-connection determinations, and thus, our conclusions are tentative. Future studies should assess the effect of additional factors to further elucidate the process of service-connection determination for back pain.

\section{CONCLUSIONS}

Based on the available data, Veterans who have lost or impaired function in their backs receive higher service connection for their conditions than those without such impairment. The findings suggest that VBA criteria for 


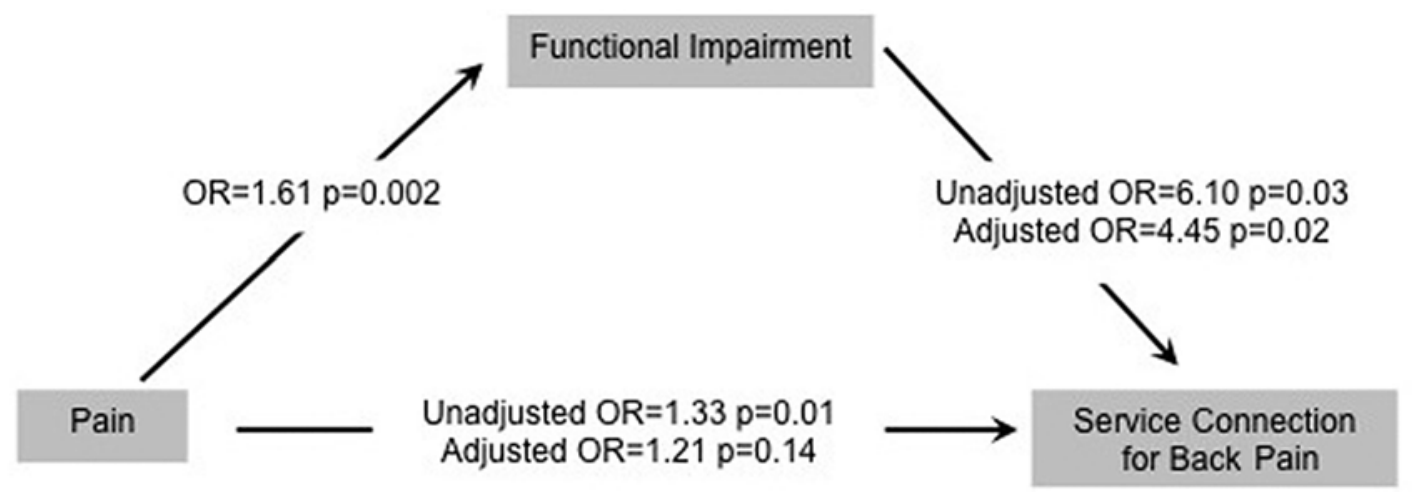

Figure.

Mediation model: Relationship between pain, functional impairment, and service connection for back pain. Service connection for back pain in this model is an ordinal outcome: (1) 0 percent, (2) $>0$ percent but $\leq 20$ percent, or (3) $>20$ percent. OR $=$ odds ratio.

service connection effectively narrow the determinants of award to functional impairment and are not independently associated with employment or with comorbid conditions that might affect real-world activities.

Applicants for service connection for back conditions have many comorbid conditions and need a variety of services. The C\&P examination is a point-of-contact opportunity to identify these needs and connect Veterans to services.

\section{ACKNOWLEDGMENTS}

\section{Author Contributions:}

Study concept and design: C. J. Sakr, A. C. Black, M. I. Rosen.

Data collection: J. Calfo.

Data management: M. D. Slade, J. Calfo.

Analysis and interpretation of data: C. J. Sakr, A. C. Black, M. D.

Slade, J. Calfo, M. I. Rosen.

Drafting of manuscript: C. J. Sakr, A. C. Black, M. D. Slade, M. I.

Rosen.

Critical revision of manuscript for important intellectual content:

C. J. Sakr, A. C. Black, M. D. Slade, J. Calfo, M. I. Rosen.

Study supervision: M. I. Rosen.

Financial Disclosures: The authors have declared that no competing interests exist.

Funding/Support: This material was based on work supported by the Pain, Research, Informatics, Medical Comorbidities and Education Center, VA Connecticut Healthcare System (Project \#LIPS 96-003) and by the National Institutes of Health, National Center for Complementary and Integrative Health (grant R34 AT008318 [Marc I. Rosen]).

Institutional Review: The study protocol was approved by the VA Connecticut Institutional Review Board.

\section{REFERENCES}

1. Gironda RJ, Clark ME, Massengale JP, Walker RL. Pain among veterans of Operations Enduring Freedom and Iraqi Freedom. Pain Med. 2006;7(4):339-43. [PMID:16898945] http://dx.doi.org/10.1111/j.1526-4637.2006.00146.x

2. Haskell SG, Ning Y, Krebs E, Goulet J, Mattocks K, Kerns R, Brandt C. Prevalence of painful musculoskeletal conditions in female and male veterans in 7 years after return from deployment in Operation Enduring Freedom/Operation Iraqi Freedom. Clin J Pain. 2012;28(2):163-67. [PMID:21677563] http://dx.doi.org/10.1097/AJP.0b013e318223d951

3. Department of Veterans Affairs (VA), Veterans Benefits Administration (VBA). Types of compensation [Internet]. Washington (DC): VA; VBA; [cited 2015 May 27]. Available from: http://www.benefits.va.gov/COMPENSATION/ types-compensation.asp

4. Department of Veterans Affairs (VA), National Center for Veterans Analysis and Statistics. Statistics at a Glance [Internet]. Washington (DC): VA; 2014 Aug [cited 2015 Apr 29]. Available from: http://www.va.gov/vetdata/docs/ Quickfacts/Homepage_slideshow_06_30_14.pdf

5. Department of Veterans Affairs (VA), Veterans Benefits Administration (VBA). Compensation [Internet]. Washington (DC): VA, VBA; 2014 [cited 2015 Apr 29]. Available from: http://www.benefits.va.gov/REPORTS/abr/ABRCompensation-FY13-09262014.pdf

6. Kang HK, Mahan CM, Lee KY, Magee CA, Murphy FM. Illnesses among United States veterans of the Gulf War: A population-based survey of 30,000 veterans. J Occup Environ Med. 2000;42(5):491-501. [PMID:10824302] http://dx.doi.org/10.1097/00043764-200005000-00006 
7. Department of Veterans Affairs (VA), Veterans Benefits Administration (VBA). Schedule for rating disabilities [Internet]. Washington (DC): VA, VBA; [cited $2015 \mathrm{Jul}$ 14]. Available from: http:/www.benefits.va.gov/warms/ bookc.asp

8. Harrington JT. Musculoskeletal pain and work disability. Wis Med J. 1992;91(10):579-80. [PMID:1441573]

9. Kleinke CL, Spangler AS Jr. Predicting treatment outcome of chronic back pain patients in a multidisciplinary pain clinic: Methodological issues and treatment implications. Pain. 1988;33(1):41-48. [PMID:2454442] http://dx.doi.org/10.1016/0304-3959(88)90201-1

10. Jamison RN, Matt DA, Parris WC. Treatment outcome in low back pain patients: Do compensation benefits make a difference? Orthop Rev. 1988;17(12):1210-15. [PMID:2975372]

11. Rosenberger PH, Kerns R, Jokl P, Ickovics JR. Mood and attitude predict pain outcomes following arthroscopic knee surgery. Ann Behav Med. 2009;37(1):70-76.

[PMID:19169766]

http://dx.doi.org/10.1007/s12160-008-9078-z

12. Gil KM, Carson JW, Porter LS, Scipio C, Bediako SM, Orringer E. Daily mood and stress predict pain, health care use, and work activity in African American adults with sickle-cell disease. Health Psychol. 2004;23(3):267-74.

[PMID:15099167]

http://dx.doi.org/10.1037/0278-6133.23.3.267

13. Oberlinner C, Yong M, Nasterlack M, Pluto RP, Lang S. Combined effect of back pain and stress on work ability. Occup Med (Lond). 2015;65(2):147-53. [PMID:25634953] http://dx.doi.org/10.1093/occmed/kqu190

14. Gaudiano BA. Service connection for PTSD is not a gender issue: Comment on Murdoch et al. Med Care. 2003;41(12): 1417-18, author reply 1417-18.

[PMID:14668674]

http://dx.doi.org/10.1097/01.MLR.0000100588.61300.A0

15. Murdoch M, Hodges J, Cowper D, Sayer N. Regional variation and other correlates of Department of Veterans Affairs Disability Awards for patients with posttraumatic stress disorder. Med Care. 2005;43(2):112-21.

[PMID:15655424]

http://dx.doi.org/10.1097/00005650-200502000-00004

16. Murdoch M, Hodges J, Hunt C, Cowper D, Kressin N, O'Brien N. Gender differences in service connection for PTSD. Med Care. 2003;41(8):950-61. [PMID:12886174] http://dx.doi.org/10.1097/00005650-200308000-00008

17. Murdoch M, Nelson DB, Fortier L. Time, gender, and regional trends in the application for service-related posttraumatic stress disorder disability benefits, 1980-1998. Mil Med. 2003;168(8):662-70. [PMID:12943044]

18. Sayer NA, Hagel EM, Noorbaloochi S, Spoont MR, Rosenheck RA, Griffin JM, Arbisi PA, Murdoch M. Gender dif- ferences in VA disability status for PTSD over time. Psychiatr Serv. 2014;65(5):663-69. [PMID:24535436]

http://dx.doi.org/10.1176/appi.ps.201300017

19. Department of Veterans Affairs (VA), Veterans Benefits Administration (VBA). Overview: Disability Benefits Questionnaires [Internet]. Washington (DC): VA, VBA; [cited 2015 Apr 29]. Available from: http://benefits.va.gov/ COMPENSATION/dbq_overview.asp.

20. Fielstein EM, Brown SH, McBrine CS, Clark TK, Hardenbrook SP, Speroff T. The effect of standardized, computerguided templates on quality of VA disability exams. AMIA Annu Symp Proc. 2006;2006:249-53.

21. Kroenke K, Spitzer RL, Williams JB. The PHQ-9: Validity of a brief depression severity measure. J Gen Intern Med. 2001;16(9):606-13. [PMID:11556941] http://dx.doi.org/10.1046/j.1525-1497.2001.016009606.x

22. Das SR, Kinsinger LS, Yancy WS Jr, Wang A, Ciesco E, Burdick M, Yevich SJ. Obesity prevalence among veterans at Veterans Affairs medical facilities. Am J Prev Med. 2005;28(3):291-94. [PMID:15766618]

http://dx.doi.org/10.1016/j.amepre.2004.12.007

23. Hoerster KD, Lehavot K, Simpson T, McFall M, Reiber G, Nelson KM. Health and health behavior differences: U.S. Military, veteran, and civilian men. Am J Prev Med. 2012;43(5):483-89. [PMID:23079170] http://dx.doi.org/10.1016/j.amepre.2012.07.029

24. Brown DW. Smoking prevalence among US veterans. J Gen Intern Med. 2010;25(2):147-49. [PMID:19894079] http://dx.doi.org/10.1007/s11606-009-1160-0

25. Bastian LA, Sherman SE. Effects of the wars on smoking among veterans. J Gen Intern Med. 2010;25(2):102-3. [PMID:20077050] http://dx.doi.org/10.1007/s11606-009-1224-1

26. Volkman JE, DeRycke EC, Driscoll MA, Becker WC, Brandt CA, Mattocks KM, Haskell SG, Bathulapalli H, Goulet JL, Bastian LA. Smoking Status and Pain Intensity Among OEF/OIF/OND Veterans. Pain Med. 2015;16(9): 1690-96. [PMID:25917639] http://dx.doi.org/10.1111/pme.12753

27. Department of Veterans Affairs (VA). Disability compensation [Internet]. Washington (DC): VA; [July 04, 2015]; Available from: http://www.benefits.va.gov/COMPENSATION/types-disability.asp.

28. Rosen MI, Ablondi K, Black AC, Mueller L, Serowik KL, Martino S, Mobo BH, Rosenheck RA. Work outcomes after benefits counseling among veterans applying for service connection for a psychiatric condition. Psychiatr Serv. 2014;65(12):1426-32. [PMID:25082304] http://dx.doi.org/10.1176/appi.ps.201300478

29. Nguyen TH, Randolph DC. Nonspecific low back pain and return to work. Am Fam Physician. 2007;76(10):14971502. [PMID:18052015] 
JRRD, Volume 53, Number 6, 2016

Submitted for publication August 7, 2015. Accepted in revised form March 15, 2016.

This article and any supplementary material should be cited as follows:

Sakr CJ, Black AC, Slade MD, Calfo J, Rosen MI. Iraq/ Afghanistan-era Veterans with back pain: Characteristics and predictors of compensation and pension award. J Reha- bil Res Dev. 2016;53(6):659-68.

http://dx.doi.org/10.1682/JRRD.2015.08.0151

ORCID: Anne C. Black, PhD: 0000-0003-0295-7351; Justin Calfo, BA: 0000-0003-2007-7251

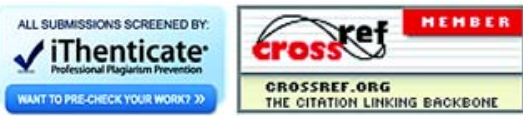

